\title{
Effects of valproate on Tax and HBZ expression in ex vivo cultured ATL cells
}

\author{
Gildas Belrose ${ }^{1}$, Hélène Gazon ${ }^{1,2}$, Jean-Côme Meniane 3 , Stéphane Olindo ${ }^{4}$, Jean-Michel Mesnard², \\ Jean-Marie Péloponèse ${ }^{2}$, Raymond Césaire ${ }^{1^{*}}$ \\ From 16th International Conference on Human Retroviruses: HTLV and Related Viruses \\ Montreal, Canada. 26-30 June 2013
}

Epigenetic drugs are known to regulate expression of tumor suppressor genes and activities of transcriptional factors involved in both cancer initiation and progression. Valproate (VPA) has been shown to enhance Tax expression and block HBZ-mRNA expression in HTLV-1 and HAM/TSP lymphocytes. HBZ is critical for immune escape and proliferation of ATL cells. We evaluated the impact of VPA on Tax, Gag and HBZ expression in ex vivo cultured ATL cells. Samples were obtained from 6 patients with acute ATL, 4 patients with HAM/TSP, and 3 asymptomatic carriers (AC). CD8+-cell-depleted PBMCs were cultured during a week with or without $5 \mathrm{mM}$ VPA. HTLV-1 mean proviral loads at day 0 of culture were 58 copies/100 cells, 7 copies/ 100 cells, and 4 copies/100 cells in ATL, HAM/TSP, and $\mathrm{AC}$, respectively. At day 5 , mean proviral loads decrease by 2 fold in VPA treated vs. untreated ATL samples. Mean \pm SD apoptosis at day 1 was $11 \% \pm 6$ in untreated versus $23 \% \pm 11$ in VPA-treated non-ATL samples, and $13 \% \pm 9$ in untreated versus $43 \% \pm 25$ in VPA-treated samples. Tax expression in CD4+ cells, measured by Facs and by qRT-PCR, peaked at day 1 of culture in AC and HAM/TSP samples but not in ATL samples. Tax and gag mRNAs were undetectable during culture of ATL untreated samples, whereas HBZ was expressed. VPA treatment of ATL samples significantly increased Tax and Gag mRNA mean levels, and blocked HBZ mRNA expression. The possibility to target HBZ expression using VPA at therapeutically useful concentrations opens a new way for the treatment of ATL.

\section{Authors' details}

${ }^{1}$ Laboratoire de Virologie and EA 4537, Centre Hospitalier Universitaire de Fort-de-France, Martinique, France. ${ }^{2}$ Centre d'Études d'Agents Pathogènes et

\footnotetext{
* Correspondence: raymond.cesaire@chu-fortdefrance.fr

'Laboratoire de Virologie and EA 4537, Centre Hospitalier Universitaire de Fort-de-France, Martinique, France

Full list of author information is available at the end of the article
}

Biotechnologies pour la Santé, CNRS UMR 5236, Université Montpellier 1, Université Montpellier 2, Montpellier, France. ${ }^{3}$ Service d'Hématologie clinique, Centre Hospitalier Universitaire de Fort-de-France, Martinique, France.

${ }^{4}$ Service de Neurologie, Centre Hospitalier Universitaire de Fort-de-France, Martinique, France.

Published: 7 January 2014

doi:10.1186/1742-4690-11-S1-P39

Cite this article as: Belrose et al: Effects of valproate on Tax and HBZ expression in ex vivo cultured ATL cells. Retrovirology 2014 11(Suppl 1): P39.
Submit your next manuscript to BioMed Central and take full advantage of:

- Convenient online submission

- Thorough peer review

- No space constraints or color figure charges

- Immediate publication on acceptance

- Inclusion in PubMed, CAS, Scopus and Google Scholar

- Research which is freely available for redistribution

Submit your manuscript at www.biomedcentral.com/submit
() Biomed Central
C Biomed Central

(c) 2014 Belrose et al; licensee BioMed Central Ltd. This is an Open Access article distributed under the terms of the Creative Commons Attribution License (http://creativecommons.org/licenses/by/2.0), which permits unrestricted use, distribution, and reproduction in any medium, provided the original work is properly cited. The Creative Commons Public Domain Dedication waiver (http:// creativecommons.org/publicdomain/zero/1.0/) applies to the data made available in this article, unless otherwise stated. 